\title{
A comparison of 5 or 7 days of rabeprazole triple therapy for eradication of Helicobacter pylori
}

\author{
Ari F. Syam, ${ }^{1}$ Murdani Abdullah, ${ }^{1}$ Abdul A. Rani, ${ }^{1}$ Siti Nurdjanah,,${ }^{2}$ Pangestu Adi, ${ }^{3}$ Ali Djumhana, ${ }^{4}$ Pangarapen \\ Tarigan, ${ }^{5}$ IDN Wibawa. ${ }^{6}$ \\ ${ }^{1}$ Division of Gastroenterology, Department of Internal Medicine, Dr. Cipto Mangunkusumo Hospital, Faculty of Medicine, University \\ of Indonesia, Jakarta, Indonesia \\ ${ }^{2}$ Division of Gastroentero-Hepatology, Department of Internal Medicine, Dr. Sardjito Hospital, Faculty of Medicine Gajah Mada \\ University, Yogyakarta, Indonesia \\ ${ }^{3}$ Division of Gastroenterology, Department of Internal Medicine, Dr. Sutomo Hospital, Faculty of Medicine, Airlangga University, \\ Surabaya, Indonesia \\ ${ }^{4}$ Division of Gastroentero-Hepatology, Department of Internal Medicine, Dr. Hasan Sadikin Hospital, Faculty of Medicine, \\ Padjajaran University, Bandung, Indonesia \\ ${ }^{5}$ Division of Gastroentero-Hepatology, Department of Internal Medicine, H. Adam Malik Hospital, Faculty of Medicine, Sumatera \\ Utara University, Medan, Indonesia \\ ${ }^{6}$ Department of Internal Medicine, Sanglah Hospital, Faculty of Medicine, Udayana University, Denpasar, Indonesia
}

\begin{abstract}
Abstrak
Tujuan Pengobatan untuk eradikasi H pylori dengan kombinasi PPI dan Amoksisilin $1000 \mathrm{mg}$ atau Clarithromycin $500 \mathrm{mg}$ yang diberikan 2 kali sehari selama 2 minggu telah terbukti efektif. Kebanyakan penelitian menyebutkan bahwa pengobatan 7 dan 10 hari sama efektif. Tujuan dari penelitian ini adalah untuk membandingkan terapi eradikasi H pylori selama 5 dan 7 hari.
\end{abstract}

Metode Penelitian ini dilakukan secara prospektif pada 60 pasien yang terinfeksi $H$ pylori, pemeriksaan dilakukan dengan endoskopi dan biopsi saluran cerna bagian atas di 6 (enam) rumah sakit di Indonesia. Diagnosis $H$ pylori ditegakkan berdasarkan pada 2 pemeriksaan rapid urea test (Pronto Dry) dan pemeriksaan histopatologi atau adanya urea breath test (UBT) yang positif. Kemudian secara terbuka pasien akan dibagi menjadi 2 kelompok, kelompok pertama mendapatkan pengobatan oral amoksisilin $1000 \mathrm{mg} 2$ kali sehari, clarithromycin oral $500 \mathrm{mg} 2 \mathrm{kali}$ sehari, rabeprazole $10 \mathrm{mg} 2 \mathrm{kali}$ sehari selama 5 hari dan kelompok kedua mendapatkan pengobatan oral amoksisilin 1000 mg 2 kali sehari, clarithromycin oral $500 \mathrm{mg} 2$ kali sehari, rabeprazole $10 \mathrm{mg} 2$ kali sehari selama 7 hari. Empat minggu kemudian, pasien dievaluasi dengan UBT untuk memastikan keberadaan H pylori.

Hasil Pada penelitian ini didapatkan 60 pasien yang terdiri dari 42 laki-laki dan 18 perempuan dengan rata-rata (usia+SD) 47.63+13.93 tahun, rentang usia 21-74 tahun. Kelompok pengobatan 5 hari terdiri dari 25 (41,7\%) pasien dan kelompok pengobatan 7 hari terdiri dari 35 (58.3\%) pasien. Setelah kelompok pengobatan 5 hari didapatkan 18 (72\%) pasien H Pylori negatif, dan setelah pengobatan 7 hari didapatkan 32 (91.4\%) pasien H Pylori negatif. Kegagalan eradikasi ditemukan pada kelompok pengobatan 5 hari sebesar 7 (28\%) pasien dan pada kelompok pengobatan 7 hari sebesar $3(8.6 \%)(p=0,077)$.

Kesimpulan Penelitian ini menunjukkan bahwa eradikasi $H$ pylori dengan pengobatan tripel dengan rabeprazole pada kelompok 7 hari masih lebih baik daripada kelompok pengobatan 5 hari. Perbedaan yang tidak bermakna secara statistik ini mungkin karena jumlah sampel tidak mencukupi. (Med J Indones 2010; 19:113-7)

\begin{abstract}
Aim A combination of PPI and $1000 \mathrm{mg}$ amoxicillin/500 mg clarithromycin twice daily for 2 weeks has been proven effective in the eradication of $H$. pylori. Most studies suggested that treatment for 7 and 10 days may be equally effective. Few data are available on the efficacy of 5-day triple therapy. Aim of this study was to compare 5-day and 7-day rabeprazole triple therapy for eradication of $H$. pylori infection.

Methods We prospectively studied 60 consecutive $H$. pylori-infected patients who came to hospitals in six centres in Indonesia and who underwent upper endoscopy and biopsy. $H$. pylori infection was confirmed if two rapid urease tests (Pronto Dry) and histology or urea breath test were positive. Patients were assigned to either an open-labelled 5-day or 7-day course of oral amoxicillin $1000 \mathrm{mg}$ b.i.d., clarithromycin $500 \mathrm{mg}$ b.i.d., and rabeprazole $10 \mathrm{mg}$ b.i.d. (RAC). Four weeks after therapy, all patients had a repeated UBT for evaluation of the presence of $H$. pylori.

Results Of the 60 patients (42 males and 18 females) with mean age ( \pm SD) $47.63 \pm 13.93$ years, range 21-74 years, 25 patients $(41.7 \%)$ had 5-day treatment and 35 patients $(58.3 \%)$ had 7-day treatment. With 5-day treatment, 18 patients (72\%) and with 7-day treatment 32 patients (91.4\%) became negative for $H$. pylori infection. The eradication failure was found on 7 patients (28.0\%) in 5-day treatment and 3 patients (8.6\%) in 7-day treatment.
\end{abstract}

Conclusions The study showed that the eradication of $H$. pylori infection by triple rabeprazole-based treatment in 7-day is still better than in 5-day. (Med J Indones 2010; 19:113-7)

Key words: $H$. pylori, rabeprazole, triple therapy 
Helicobacter pylori (H. pylori) can infect the stomach during childhood and cause chronic gastritis leading to peptic ulcer. ${ }^{1}$ This infection is also classified as a class 1 stomach carcinogen. ${ }^{2}$ More than $50 \%$ of the population of western countries suffer from this infection and 80$90 \%$ of the population of developing countries has at some time been infected by this bacterium. ${ }^{3}$

Re-infection is rare in adults because the treatment results in permanent eradication of the infection, thus preventing further complications such as peptic ulcer, which can lead to perforation and bleeding, and also in turn leading to raising the general standard of health ${ }^{4}$

At present, there is still no standard composition or duration for the therapeutic regimen, because sufficient research to establish the most effective regimen has not yet been carried out. At present, a combination of three drugs is used: a proton pump inhibitor (PPI) with any two of the antibiotics amoxicillin, clarithromycin, metronidazole or trinidazole. This achieves a bacterial eradication rate of greater than $85 \%$.

A combination of PPI and $1000 \mathrm{mg}$ amoxicillin/500 mg clarithromycin twice a day has been proven effective in the eradication of $\mathrm{H}$. pylori. ${ }^{5}$ Most studies have used all three drugs twice daily for 2 weeks. Other trials in the Asian region have suggested that treatment for a shorter period of time, 7-10 days, may be nearly as effective. ${ }^{6}$ To the present, only a few studies that have used triple therapy for a short time (5 days). If this is as effective as 7 days triple therapy, this shorter therapy could be used for patients in developing countries such as Indonesia.

The objective of this study was to compare 5-day and 7-day rabeprazole triple therapy for eradication of $H$. pylori infection.

\section{METHODS}

This was a multicentre, randomized controlled trial that included six centres in Indonesia: Jakarta, Bandung, Jogjakarta, Surabaya, Medan and Denpasar. Five centres in Indonesia recruited six or more patients. Patients with $H$. pylori infection were included in this study. The following criteria applied to the patients to be admitted to the study: signed informed consent, positive for $H$. pylori with two positive test results from the rapid urea test (Pronto Dry) and positive for histology or urea breath test (UBT), aged over 18.
The patients did not use antibiotics or proton pump inhibitors (PPI) for 1 week before the study. Patients who had an allergy to amoxicillin or clarithromycin or a history of severe liver disease and renal failure and any significant symptoms such as weight loss, gastrointestinal bleeding, jaundice or other serious disease were excluded. We also excluded pregnant and lactating women.

All patients fulfilling the requirements underwent endoscopy. At endoscopy, evaluation of two antral and two corpus biopsy specimens were obtained. One biopsy from the antrum and one biopsy from the corpus were used for the Pronto Dry test and the others were used for histological examination. Specimens for histology were stained with haematoxylin and eosin. An experienced gastrointestinal pathologist reviewed all specimens.

\section{Histopathological examination}

Biopsy specimens for histopathological examination were fixed in buffered $4 \%$ formalin overnight and embedded in paraffin. Two $4 \mathrm{~mm}$ sections were stained with haemotoxylin-eosin and one section was stained by the modified Giemsa procedure. The slides were microscopically examined using high power and at least five high-power fields were examined. If $H$. pylori was observed the bacterial density was scored semi-quantitatively on an ordinal scale $(0-3)$ by a single pathologist. A single pathologist performed the histological evaluation of gastric mucus. Histology grades for $H$. pylori density, polymorphonuclear neutrophil activity, chronic inflammation, glandular atrophy and intestinal metaplasia were classified according to the updated Sydney System. Positive results for $H$. pylori were based on a positive result from either the rapid urease test or microscopic detection of $\mathrm{H}$. pylori.

\section{Study design and medication}

Sixty $H$. pylori-infected patients were randomized to one of the following two groups:

- Rabeprazole10mg/amoxicillin1000mg/clarithromycin $500 \mathrm{mg}$ b.i.d for 7 days

- Rabeprazole10mg/amoxicillin1000mg/clarithromycin $500 \mathrm{mg}$ b.i.d for 5 days

During treatment, the patients assessed their upper gastrointestinal symptoms and use of medication on a diary card and returned all remaining medications at follow-up. We also noted the patients' complaints after treatment. Four weeks after treatment, a urea 
breath test was performed. The cure rate was defined as the number of successfully treated patients divided by the number of successfully treated plus the number of unsuccessfully treated patients. The cure rate was evaluated by per protocol analysis.

\section{Statistical analyses}

The result was analysed by a statistician. Univariate values were expressed as mean, standard deviation (SD), minimum and maximum. Bivariate analysis by independent $t$ test to compare means and two-sided Fisher's exact test $\left(c^{2}\right)$ with 95\% confidence interval (CI) were used to assess the significant differences between values in the two groups of patients. A probability $(p)$ value of less than 0.05 was considered significant. Statistical analyses were conducted using SPSS version 16.

\section{RESULTS}

Of the 60 patients, consisting of 42 males (70\%) and 18 females (30\%) with mean age ( \pm SD) $47.63 \pm 13.93$, range $21-74$ years, 25 patients (41.7\%) and 35 patients (58.3\%) respectively completed 5-day and 7-day treatment (Table 1).

Table 1. Baseline characteristics of the 5- and 7-day groups

\begin{tabular}{lcc}
\hline & $\begin{array}{c}\text { 5-day RAC group } \\
(\mathrm{n}=25)\end{array}$ & $\begin{array}{c}\text { 7-day RAC group } \\
(\mathrm{n}=35)\end{array}$ \\
\hline Male & 15 & 27 \\
Female & 10 & 8 \\
Mean age (yr) & $47.44 \pm 14.47$ & $47.77 \pm 13.74$ \\
Age range (yr) & $21-74$ & $22-74$ \\
\hline
\end{tabular}

RAC: Rabeprazole 10 mg b.i.d, amoxicillin 1000 mg b.i.d., clarithromycin 500 mg b.i.d.

In the 5-day treatment group there were 15 males (60\%) and 10 females (40\%) aged ( $( \pm S D) 47.44 \pm 14.47$ years, range 21-74 years, while in the 7-day treatment group there were 27 males (77.1\%), 8 females (22.9\%) aged $47.77 \pm 13.74$, range $22-74$ years.

After treatment, $H$. pylori was eradicated in 18 patients (72\%) given 5-day treatment and 32 patients (91.4\%) given 7-day treatment, while eradication failure was founded on 7 patients (28.0\%) in 5-day treatment and 3 patients (8.6\%) in 7-day treatment. This eradication rate was based on per protocol analysis. (Table 2).
Table 2. Association between duration of treatment and the outcome in patients who underwent triple therapy

\begin{tabular}{cccccc}
\hline \multirow{2}{*}{$\begin{array}{c}\text { Treatment } \\
\text { group }\end{array}$} & \multicolumn{4}{c}{ Outcome of treatment } & $\mathrm{P}$ \\
\cline { 2 - 4 } & H. pylori Negative & \multicolumn{2}{c}{ H. pylori Positive } & Value \\
\cline { 2 - 4 } & $\mathrm{n}$ & $\%$ & $\mathrm{n}$ & $\%$ & \\
\hline 5-day group & 18 & 72.0 & 7 & 28.06 & 0.077 \\
7-day group & 32 & 91.4 & 3 & 8.6 & \\
\hline
\end{tabular}

\section{DISCUSSION}

Even though many different therapeutic regimens have been studied for $H$. pylori eradication in acid-related disorders, $^{7,8} 1$-week PPI-based triple therapy has been widely accepted as the standard treatment of peptic ulcer with $H$. pylori infection. ${ }^{9-11}$ However, the optimal duration of triple therapy remains to be established. More recently, many newer PPIs have been developed that possess the ability for potent and rapid inhibition of gastric acid secretion. ${ }^{2,13}$ Therefore, short-term regimens ( $<7$ days) have been suggested for the eradication of $H$. pylori infection.

A new PPI, rabeprazole, has been demonstrated to be effective in the treatment of acid-related disorders including peptic ulcer disease. ${ }^{16-18}$ Rabeprazole rapidly and potently inhibits gastric acid secretion. In addition, this PPI can induce earlier stabilization of antibiotics and has a higher rate of eradication of $H$. pylori compared with other PPIs.

Several studies have compared the eradication rate of a short-term course with that of standard course rabeprazole-based triple therapy for $H$. pylori infection. In a study by Wang et al. ${ }^{21}$, the eradication rate decreased from $84.6 \%$ to $78.4 \%$ in the 3-day group and from $87.5 \%$ to $81.6 \%$ in the 7-day group tested between three months and 12 months after rabeprazole-based triple therapy.

Our study showed that a 5-day rabeprazole-based triple therapy regimen had lower eradication rates $(72.0 \%$ vs. $91.4 \%, p=0.077$ ) against $H$. pylori infection compared with a 7-day rabeprazole-based triple therapy regimen. The non statistical significance was likely due to small sample size.

The differences between our study and Wang's previous study are that we gave the drugs (amoxicillin $1000 \mathrm{mg}$, clarithromycin $500 \mathrm{mg}$ and rabeprazole $10 \mathrm{mg}$ ) twice daily for 5 or 7 days, then evaluated at 4 weeks. In Wang et al.'s study they gave $20 \mathrm{mg}$ rabeprazole twice in 3 days or 7 days. $^{21}$ 
There is no doubt that an ideal $H$. pylori treatment must be safe, cheap, easy and tolerable with more than $80 \%$ eradication rate and must have a low rate of antibiotic resistance. ${ }^{22,23}$ Although treatment failures of $H$. pylori eradication are influenced by several factors, many of the currently used $H$. pylori eradication regimens fail to cure the infection because of either antimicrobial resistance or poor patient compliance. ${ }^{24,25}$ In the past, there have been concerns in many studies about antimicrobial resistance of $H$. pylori resulting from eradication therapy. ${ }^{26,27}$ H. pylori clarithromycin resistance is the main factor impairing the efficacy of standard triple therapy. $H$. pylori resistance against clarithromycin is increasing worldwide, but our data show that the success rate of 7-day triple therapy using clarithromycin is still good (91.4\%).

The study showed that the eradication of $H$. pylori infection by triple rabeprazole-based treatment in 7-day is still better than in 5-day for peptic ulcer with $H$. pylori infection disease at the recent. However, more samples are needed for further evaluating the effectiveness between these 2 treatments.

\section{Acknowledgments}

This study was supported by PT Eisai Indonesia.

\section{REFERENCES}

1. De Boer WA, Tygat GNJ. Treatment of Helicobacter pylori infection. Br Med J 2000; 320: 31-4

2. Vaira D, Malferheiner P, Megraud F, et al. Diagnosis of Helicobacter pylori infection with a new non-invasive antigen-based assay. Lancet 1999; 354: 30-3

3. Vaira D, Miglioli M, Mule P, et al. Prevalence of peptic ulcer in Helicobacter pylori positive blood donors. Gut 1994; 35: 309-12

4. Wilhelmsen I. Quality of life and Helicobacter pylori eradication. Scand J Gastroenterol. 1996; 31(Suppl 221): $18-20$

5. Fennerty MB, Kovacs TO, Krause R, et al. A comparison of 10 and 14 days of lansoprazole triple therapy for eradication of Helicobacter pylori. Arch Intern Med. 1998; 158(15):1651-6

6. Wong BC, Xiao SD, Hu FL, et al. Comparison of lansoprazole-based triple and dual therapy for treatment of Helicobacter pylori-related duodenal ulcer: an Asian multicentre double-blind randomized placebo controlled study. Aliment Pharmacol Ther. 2000; 14(2):217-24

7. Hopkins RJ, Girardi LS, Turney EA. Relationship between Helicobacter pylori eradication and reduced duodenal and gastric ulcer recurrence: A review. Gastroenterology 1996; 110: $1244-52$
8. Lam SK, Talley NJ. Report of the 1997 Asia Pacific Consensus Conference on the management of Helicobacter pylori infection. J Gastroenterol Hepatol. 1998; 13: 1-12

9. European Helicobacter pylori Study Group. Current European concepts in the management of Helicobacter pylori infection. The Maastricht Consensus Report. Gut 1997; 41: 8-13

10. Lind T, Veldhuyzen van Zanten S, Unge P, et al. Eradication of Helicobacter pylori using one-week triple therapies combining omeprazole with two antimicrobials: The MACH I Study. Helicobacter 1996; 1: 138-44

11. Miwa H, Ohkura R, Murai T, Nagahara A, Yamada $\mathrm{T}$, Ogihara $\mathrm{T}$, Watanabe $\mathrm{S}$, Sato $\mathrm{N}$. Effectiveness of omeprazole-amoxicillin-clarithromycin (OAC) therapy for Helicobacter pylori infection in a Japanese population. Helicobacter 1998; 3: 132-8

12. Pantoflickova D, Dorta G, Ravic M, Jornod P, Blum AL. Acid inhibition on the first day of dosing: comparison of four proton pump inhibitors. Aliment Pharmacol Ther. 2003; 17: 1507-14

13. Welage LS. Pharmacologic properties of proton pump inhibitors. Pharmacotherapy 2003; 23 (10 Pt 2): 74S-80S

14. Hsieh YH, Lin HJ, Tseng GY, Perng CL, Chang FY, Lee SD. A 3-day anti-Helicobacter pylori is a good alternative for bleeding peptic ulcer patients with Helicobacter pylori infection. Hepatogastroenterology 2001; 48: 1078-81

15. Grimley CE, Penny A, O’Sullivan M, Shebani M, Lismore JR, Cross R, Illing RC, Loft DE, Nwokolo CU. Comparison of two 3-day Helicobacter pylori eradication regimens with a standard 1-week regimen. Aliment Pharmacol Ther. 1999; 13: 869-73

16. Dekkers CP, Beker JA, Thjodleifsson B, Gabryelewicz A, Bell NE, Humphries TJ. Comparison of rabeprazole $20 \mathrm{mg}$ vs. omeprazole $20 \mathrm{mg}$ in the treatment of active gastric ulcer-a European multicentre study. The European Rabeprazole Study Group. Aliment Pharmacol Ther. 1998; 12: 789-95

17. Dekkers CP, Beker JA, Thjodleifsson B, Gabryelewicz A, Bell NE, Humphries TJ. Comparison of rabeprazole $20 \mathrm{mg}$ vs. omeprazole $20 \mathrm{mg}$ in the treatment of active duodenal ulcer: A European multicentre study. The European Rabeprazole Study Group. Aliment Pharmacol Ther. 1999; 13: 179-86

18. Tsutsui N, Taneike I, Ohara T, Goshi S, Kojio S, Iwakura N, Matsumaru H, Wakisaka-Saito N, Zhang HM, Yamamoto T. A novel action of the proton pump inhibitor rabeprazole and its thioether derivative against the motility of Helicobacter pylori. Antimicrob Agents Chemother 2000; 44: 3069-73

19. Kositchaiwat C, Ovartlarnporn B, Kachintorn U, Atisook K. Low and high doses of rabeprazole vs. omeprazole for cure of Helicobacter pylori infection. Aliment Pharmacol Ther. 2003; 18: 1017-21

20. Prakash A, Faulds D. Rabeprazole. Drugs 1998; 55: 261-7

21. Wang HH, Chou JW, Liao KF, Lin ZY, Lai HC, Hsu CH, Chen CB. On 1-year follow up study of Helicobacter pylori eradication rate with ${ }^{13} \mathrm{C}$-urea breath test after 3-day and 7-day rabeprazole-based therapy. World J Gastroenterol. 2005; 11(11): 1680-84 
22. Rauws EA, van der Hulst RW. Current guidelines for the eradication of Helicobacter pylori in peptic ulcer disease. Drugs 1995; 50: 984-90

23. Working Party of the European Helicobacter pylori Study Group. Guidelines for clinical trials in Helicobacter pylori infection. Gut 1997; 41(Suppl 2): S1-9

24. Alarcon T, Domingo D, Lopez-Brea M. Antibiotic resistance problems with Helicobacter pylori. Int J Antimicrob Agents 1999; 12: 19-26

25. Mendonca S, Ecclissato C, Sartori MS, et al. Prevalence of Helicobacter pylori resistance to metronidazole, clarithromycin, amoxicillin, tetracycline, and furazolidone in Brazil. Helicobacter 2000; 5: 79-83

26. Mollison LC, Stingemore N, Wake RA, Cullen DJ, McGechie DB. Antibiotic resistance in Helicobacter pylori. Med J Aust. 2000; 173: 521-3

27. Megraud F. Resistance of Helicobacter pylori to antibiotics: The main limitation of current proton-pump inhibitor triple therapy. Eur J Gastroenterol Hepatol. 1999; 11(Suppl 2): S35-7 